\title{
Faith in the Unexpected: The Event of Obligation in Teaching
}

\author{
Anne M. Phelan and Melanie D. Janzen
}

\begin{abstract}
In the face of standardization and rationalization, the language of the expected, the predictable and the planned has enveloped teaching and teacher education worldwide. However, in a recent study about the emotional toll of teaching in two Canadian provinces, teachers' stories overflowed with allusions to the unexpected, the unplanned, and the unforeseeable. We explore those stories, and in the company of John Caputo's writing about teaching and ethics, we speculate what they suggest about a life lived in teaching. We posit that obligation is the insistent ghost that haunts teaching in the midst of the machinery of schooling.
\end{abstract}

\section{Faith in the Unexpected: The Event of Obligation in Teaching}

Some unknown spirit, something, je ne sais quoi, comes over us and asks something of us, asks for our faith.... (Caputo, 2012b, p. 28)

I have a job and I'm paid to do it and I could just stick to it, but I'm with those kids and I know... I can't just walk away from it. (lan, High School Teacher)

As teacher educators, we find ourselves preoccupied with preparing new teachers for the classroomcurriculum planning, teaching strategies, teacher-student relationships, and classroom management-so that they can anticipate, understand, and meet their responsibilities as teachers. So, when after a short practicum, a teacher candidate confides that, "Teaching was not what I expected," we may feel admonished and wonder what we might have done differently. But, how do we prepare teacher candidates for what they cannot foresee, when by definition no one can anticipate the unexpected? Moreover, it may seem unreasonable to trust or rely on or have confidence in the unforeseen. Surprises can undo even the experienced teacher, and for the teacher candidate to look bewildered or hesitant is often tantamount to appearing incompetent. And yet, the capacity to be open to surprise, to be hospitable to hesitation, and to embrace bewilderment may be precisely what teaching demands of teachers. Could it be that having spent so much time in pre- and in-service teacher education dealing with the expected, we have barely considered what it might mean to nurture faith in the unexpected?

Consider lan, a teacher in a large urban high school. There is little doubt that lan has lost faith in the objective conditions of schooling, as he notes the lack of human and material resources to meet the needs of non-English-speaking, refugee, and immigrant students. Teaching is not what he expected. lan marched alongside his students and their parents protesting imminent school closure and ever-dwindling resources for English-language learning - a deed certainly beyond the commitments of his contract. As he witnesses his colleagues leaving, he wonders about the possibilities of a life beyond the school, the 
district, and the profession. But still he remains. When asked why, Ian answers, "I have a job and I'm paid to do it and I could just stick to it, but I'm with those kids and I know...I can't just walk away from it." What is "it," that exceeds doing the "job" one is "paid to do," to as a teacher? What is it that prevents Ian from continuing with the job as contractually defined? How does his work with "those kids" — the children of the working poor in his school neighbourhood-interrupt the logic of lan's teaching contract and provoke an unanticipated promise?

Our conversations with teachers like lan suggest to us that he is clinging to a "perhaps" — a desire that sometime, in the future, somehow, something might be otherwise. lan has faith in the unexpected. As he says, he can't just walk away from it. It is this spectral "perhaps" that intrigues us in teachers' stories about teaching, and we have found in John Caputo's writing (1993; 2012a/b) conceptual resources that help us to identify, explore, and appreciate teachers' experience of the unexpected. In turn, the teachers' stories enliven Caputo's more abstract musings. Caputo (2012b) writes that the ghost that haunts teaching is an "insistent spirit" that "insists" in the midst of what exists-the machinery of schooling-where it provokes teachers' attention. At the same time, the ghost "is all but overwhelmed, nearly invisible, nearly nothing at all..." (p. 24). What, on the one hand, could be so strong as to compel teachers and yet, so weak, as to be almost invisible? What could be so unexpected-often coming out of nowhere and anonymous - and yet feel so close to home, so personal? What could provoke disequilibrium and yet, enable balance? What could make such little sense and yet, for some, invoke a feeling of purpose and possibility? Caputo (2012b) responds that it is the call of obligation—as the event—-that compels teachers:

Whoever enters the spectral space of the school is answering a call, responding to some spirit calling us together here in common cause. What calls? What does it call for? Who is being called upon? To what future does it call us forth? (p. 30)

In this article, we explore each of the foregoing questions posed by Caputo (2012a/b), and we do so in the company of teachers who shared their stories of the unexpected with us. These stories were generated in the context of conversations about the emotional toll of teaching and its implication in teachers' decisions to stay in teaching or to leave (see Janzen \& Phelan, 2015; 2019). We asked teachers to speak about times when they felt anxious, conflicted, ashamed, surprised, fearful, and overwhelmed; times when they felt ready to leave teaching, felt they should stay, or felt ambivalent about both options. What teachers offered us were descriptions of encounters with others-students, parents, and colleagues-that required them to reach beyond the banalities of everyday life, beyond their contractual duties, to acknowledge and bear the uncertainties and ambivalences of existence among other human beings, and to take a leap of faith.

In the face of the "standardization, rationalization, and mathematicization" (Taubman, 2014, p. 128)the language of the expected, the predictable, and the planned for that has enveloped teaching worldwide-teachers' stories overflowed with allusions to the unexpected, the unplanned, and the unforeseeable. We wish to speculate about the stories they told us and what they might mean for a life lived in teaching. As such, we issue no grand claims about teaching and offer no advice to teachers or teacher educators. Rather, we try to articulate and explore what is often difficult to put into language 
about teaching. Our understandings of teachers' stories are at once tentative and fragile, but we hope they may resonate with other teachers and teacher candidates, as they have with us.

\section{What Calls?}

This call, which is not a command or a direct order, has a certain force, but it is perforce a spectral force, a weak and unforced force, with no army to endorse it. (Caputo, 2012b, p. 28)

[Y]ou live under a fear of irresponsibility. (Cecille, High School Teacher)

Cecille is an art teacher-an artist and a teacher-who "used to love" teaching. In our conversation with her, she explains her reasons for taking an extended leave of absence from teaching: "I lost faith. I lost faith in everyone...in everything. I didn't feel able to do my work properly anymore." Expressing her deep dissatisfaction with the "treatment of teachers by government and union," Cecille states that, "everybody is in overload mode." With 19 classes per week, five to 10 designated special needs students per class, 325 students to manage, and a precarious .8 teaching position, Cecille declares that students, teachers, and the disciplines deserve better. While acknowledging that the full inclusion of students with special needs is an important educational policy, Cecille insists that she is unable to meet the needs of so many "traumatized" students with "extreme...severe mental and emotional needs."

Dissatisfied with the status quo of schooling and "haunted by what insists in the midst of what exists" (Caputo, 2012b, p. 32) — the appeals of those students with special educational needs and the inability to offer some form of repair-can make a teacher frantic, restless, and uneasy with the present. While Cecille can point to visible working conditions, it is "what is going on invisibly in what visibly happens" (p. 26) that disturbs her. "[W] hat is that if not a ghost?" Caputo asks (p. 26). The ghost is obligation.

"[Y]ou want all your students to succeed," Cecille declares, but she continues. Teaching became a form of "Chinese water torture" for her, a process in which water is slowly dripped onto a person's forehead, allegedly making the restrained victim insane. She worries about appearing "mad" or unduly agitated to colleagues and school leaders. But would composure be an appropriate response to the feelings of failing traumatized students? Are teachers socialized to read agitation "as a personal [rather than institutional or systemic] failure... as a fatal flaw in the otherwise reasonable surface of our existence" (Ruti, 2014, p. 15)? Do teachers learn not to be spooked by ghosts, thereby retaining the appearance of professional competence and conduct?

Professional codes of conduct constitute a "strong" form of ethics. Such codes are of the order of a closed system or program mandating "principles that force people to be good... clarif[ying] concepts, secur[ing] judgements, provid[ing] firm guardrails along the slippery slopes of factical life" (Caputo, 1993, p. 4). Declarative statements in teaching codes of conduct such as: "The teacher teaches in a manner that respects the dignity and rights of all persons without prejudice as to..." (The Alberta Teachers' Association, 2018) leave little open to chance. Professional codes seduce with their predictability, potentiality, and actuality. In conveying certainty and possibility, however, they erase the real possibility that things might not turn out as hoped. As such, strong ethics are an affront to faith in the unexpected. They induce a fear of being irresponsible, as Cecille attests, where responsibility exists only within the 
terms of the law or code, protecting one from the wrath of parents, school leaders, or colleagues. Being responsible in this sense promises a risk-free existence-a faith in the expected, the solid, and the planned.

As a "weak" form of ethics, obligation does not tarry with the law of "duty" but exists "without owing, without ought, without why" (Caputo, 2012b, p. 25). A teacher ought to teach in a manner that respects the dignity and rights of all persons, but in the face of overwhelming work conditions, Cecille cannot. She knows that she cannot because obligation "insinuates itself into and unsettles what seems settled" (p. 29) in the official teaching standards. Cecille feels her obligation intensely; she is haunted by it. Obligation may be a weak form of ethics, but it is insistent. As a "spirit" —an ethos or a call—-that haunts schooling, obligation implicates teachers but is not as easily felt perhaps by policymakers who do not have to come face-to-face with particular students and bear witness to their daily challenges. Obligation summons faithfulness to the exceptional and the unexpected (Caputo, 2012a/b; Ruti, 2014); faithfulness to situations that cannot be anticipated in advance nor can responses to them be forethought. Teaching is tortuous for teachers who because of work conditions disallow them from answering the call of obligation. A sense of disappointment in the system and a sense of inadequacy in one's self generates disillusionment in the promise of education. Faith in the event, in its insistence, and in its real possibility is paramount. As a weak form of ethics, obligation signifies an "undoing of ethics and the possibility of a deconstruction of ethics" represented in professional codes and teaching standards (Scott, 1995, p. 250).

\section{What calls? Obligation calls!}

What Does It Call For?

[S]chools... how to keep them in creative disequilibrium without tipping over, how to spook their complacency with the promise/risk of the future.... (Caputo, 2012b, p. 29)

Well, one of the male teachers that had been sitting in this little [school] restaurant was absolutely lit on fire by [two youths kissing]. He stood up and he's saying under his breath, "Those Goddamn faggots!" and... he started yelling at the kids and telling them to get the hell out of there...." (Sara, Middle School Teacher)

Sara's narrative turns on an experience she had as a first-year teacher when she witnesses what she characterizes as a senior colleague's "very homophobic" response to students kissing in the school cafeteria. What "stupefies" her, however, is her own silence and inaction as well as that of other colleagues who witness the scene: “I didn't do anything. I didn't tell. I didn't make a complaint. I didn't talk to my union.... Nobody else in the entire room did anything and everybody saw the way that he reacted. Nobody did anything." Sara goes on to describe her fear about "breaking the rules" and not wanting "to get another teacher in trouble." She explains that, at the time, she was worried that "everybody would think that [she] was overreacting." Her recourse to a strong form of ethics-her code of professional ethics-left her wanting. Sara describes her feelings of shame at having "let it happen" and "not say[ing] anything" as intense and entangled with feelings of self-disgust and disappointment in the teacher she was becoming. Feeling disloyal to her potential, the incident prompts Sara to devote her professional life to working with and advocating for LGBTQ youth. 
Spooked by obligation, the incident in the school cafeteria precipitates a turn in Sara's life. The event has "a vocational force, provoking [her], evoking [her] response, transforming [her] life" (Caputo, 2012b, p. 31). Ethical teaching becomes about something more than a professional code for Sara; she studies the research literature on social justice and becomes "an expert," in her own words. As we see from Sara's experience, "the event [of obligation] is what allows invention, inventiveness, and reinventability, effecting a well-tempered dis/order" (p. 32). The event of obligation resists a closed order or system wherein everything is run by rules; as such, obligation allows for surprises and, at times, even demands unruliness. Sara copes with a degree of upheaval by translating the event into a calling-“a purpose beyond our normal way of going about our lives" (Ruti, 2014, p. 125).

Pinar (2020) characterizes the concept of calling as spiritual and sees teaching as one of several professions that share this "sacred subtext" (p. 202). Acknowledging that the call comes from the world, Pinar recognizes that the world also exists inside us-in the voice of conscience. The call reminds one of a greater possibility for the self and draws one back from the everyday preoccupation in the world. While "the actual performance of the call does not... lie within the self's own power of choice, the failure to hear the call does, at some level, involve a decision for which the self is responsible" (Sikka, as cited in Pinar, 2020, p. 202).

Sara seems to appreciate this responsibility. She experiences the moment in the school cafeteria as "an unexpected flash of insight" (Ruti, 2014, p. 124) that massively alters the trajectory of her teaching life. The event overtakes her without warning, but she is open to it and willing to reexamine its contentsthe details of her inaction and the values that contoured subsequent actions. Sara converts private desire (conscience?) into public service (Pinar, 2020).

What does it call for? It calls for a response.

Who Is Being Called Upon?

Obligation is the event of someone, of something personal in the midst of [this] inarticulate rumble of events. (Caputo, 1993, p. 246)

Stephen was hospitalized for...a suicide attempt. And his parents said, "we're done with you, we've had enough of the drama," so they didn't even go to the hospital to pick him up.... So I, [with] the police, went and picked him up... (Doug, High School Teacher)

Doug came to know Stephen in the midst of namelessness that characterizes crowded high schools, pervaded by "shallow forms of sociality" (Ruti, 2014, p. 89) where relationships among teachers and students are often held together by routine, convenience, and duty, rather than any real connection. One teacher commented on the challenges resulting from "the numbers...hundreds of students" combined with a "timetable set up in such a way that the [class] periods are 40 minutes.... Everything felt completely unmanageable." Crowded spaces, Ruti (2014) cautions, "force us to live on the surface because the surface is the only thing that the crowd understands" (p. 89).

How then does obligation overcome the anesthetizing features of sociality in schools? 
To say obligation happens-it happens-is not to say that obligation is impersonal. In fact, "it is that from which the personal arises and to which the personal returns" (Caputo, 1993, p. 238). Put simply, "a person is a place where obligations happen, where 'someone' says ' $\mathrm{I}$ ' to 'me,' where 'you' call upon 'me,' where 'they' call upon 'me' or 'us'" (p. 238). A person "is a place where the eyes of the other come over me, overtake me, pulling me up short. From obligations a whole network of interpersonal relations springs up; in persons a whole network of obligations takes root" (p. 238).

As Doug comes to know Stephen, Stephen comes to know Doug, like a glimmer of light, perhaps, in the midst of a cold darkness that stretched from school to home and back again. On that day, in relation to Stephen, Doug is "irreplaceable" in Levinasian terms. Doug explains:

So I, [with] the police went and picked him up, and uh, took him to a friend's house because his parents said, "Don't, don't bring him home...." [And Stephen explained to me:] "Well, I have no place to live, and I have no food to eat." So... I took him downtown to the shelter, to the Salvation Army, and said, "Well, here's a bed for the night until we figure something out, right?"

Here, educational activity - encounters between teachers, students, and the world - appears in all the rawness of obligation, amplifying the person-to-person encounter beyond prescribed institutional roles and teacher professional codes of ethics. The encounter between teacher and student is an encounter between persons - arguably the essence of human living - "the form that this encounter takes is the meaning of life" (Huebner, 1975, p. 227). Huebner continues:

The encounter is not used to produce change, to enhance prestige, to identify new knowledge, or to be symbolic of something else. The encounter is. In it is the essence of life. In it life is revealed and lived. The student is not viewed as an object, an it; but as a fellow human being, another subject, a thou, who is to be lived with in the fullness of the present moment or the eternal present. (p. 227; italics in the original)

As such, students' encounters with each other, the world around them, and the teacher, constitute the fullness of the educational activity; the encounter is all there is. "The educational activity is life-and life's meanings are witnessed and lived in the classroom" (Huebner, 1975, p. 228), and, we would add, outside it. Our concern is not with "the significance of the educational act for other ends, or the realization of other values, but the value of the educational act per se" (p. 227). We are not suggesting that a deep and long-lasting personal relationship needs to form between teachers and students, like Doug and Stephen. What obligation asks of a teacher is to "be totally and non-selectively present to the student— to each student—as he [sic] addresses me. The time interval may be brief but the encounter total" (Noddings, 1984, p. 180). While we have little understanding of the value for Stephen-though we suspect it was significant-the impact of this encounter on Doug compelled him to ask, as he put it, "What's happening here?" But there is little time to wonder about the failure of the social system, the sheer difficulty of growing up, the challenges of parenting, or of simply staying alive. Rather, Doug is compelled to "lend a hand when the damage threatens to run beyond control, to help restore the possibility of joy, the rhythm of ordinary things" for this vulnerable student (Caputo, 1993, p. 243). 
When person-to-person encounters occur, those involved may find operating outside of prescribed institutional roles; ironically, the "who" of the teacher or of the student may become unrecognizable as such. There are times when we have "to suspend the relatively organized structure of our identity [as teachers] by letting ourselves fall into a less organized state of being" (Ruti, 2014, p. 123). These are times when we feel so powerfully called to respond that we may feel as if we have no choice but to obey. There is no room for deliberation. Ruti (2014) characterizes such moments as involving a "'swerve of passion: a sudden upsurge of passion that overpowers, and sometimes even erases, our usual sources of passion" (p. 124). These moments invoke a desire that undoes a conscious desire (Caputo, 1993). Just about to leave school for the day, looking forward to a family birthday celebration or just some time at the local gym, a teacher receives a phone call from the police telling him about the student's imminent release from hospital and the parents' refusal to have their son back in their home. The moment is as "terrifying as it is exhilarating" (Ruti, 2014, p. 124), as Doug immediately drives to the hospital to pick up Stephen.

Who is being called upon? You!

To What Future Does It Call Us Forth?

Teaching occupies the cracks and crevices in the present where the present is broken open by some coming spirit. The students are the future, the future we do not see, either because we never see them again, or because they are the future generations which outlive us, so that whatever gifts we have given are given to a future in which we will never be present, an absolutely spectral future in which we will be but shades. (Caputo, 2012b, p. 30)

I'm not waiting...I'm just saying okay I'll just start taking that leap of faith and just saying let's just see what happens, like go ahead and start acting as if.... (Justin, High School Teacher)

As a newcomer to an Indigenous community, Justin is surprised by teaching colleagues who make no effort to participate in the community; by the absence of resources with which to implement a drama program; and by the complete lack of extracurricular activities for youth. Justin witnesses history in the "cracks and crevices" of the present; it is a history of cultural genocide and obligation and it haunts him. During our interview with him, he pauses to address his Indigenous students directly:

How do I, how do I achieve that? I can't. I can't fix so much that you're-that you need fixed.... There's only so much that I can do and from a 13-year old's or five-year old's perspective, is that enough?

As if in response to his questions, he recalls an encounter with one of the community Elders who asks that Justin simply respect the students and have high expectations for them. But what, Justin worries, if I make promises that I cannot keep. The risk is palpable. Then something else happens.

In the aftermath of the accidental death of an Indigenous student on the school playground, Justin attends several ceremonies hosted by the community. He describes a moment during one of the ceremonies when, "[o]ne older student in the class...touched my shoulder...just like a sense of like comfort. And that was really powerful and made a big difference in the support that I felt." Contact and accompaniment are important when language does not have the power to say what has to be said because words appear 
"vacuous and absurd" (Lingis, 1994, p. 108), or because institutional hierarchy forbids it. It was as if the student was saying that it's okay, teacher, "see what comes" (Caputo, 2012b, p. 32). The student's simple but powerful gesture conveys the possibility of making new promises and the possibility of asking forgiveness, should things not work out as hoped. Justin described that particular healing ceremony as one of

the key points where at least my perception of how I fit within the community changed. And how I felt supported and it's like the school system is lacking a system, but the community has, like, a system of care.

Faith in the unexpected is challenging and may depend on the often imperceptible but powerful presence of others - the ones who come bearing the gift of hospitality; the ones we didn't expect.

Believing in what might be possible in the midst of the impossible is an act of faith, as Justin understands. Despite the historical precarity of the school community and the insecurity of his own teaching position, Justin makes what he characterizes as "a serious commitment" to the student council to raise $\$ 22,000$ to collaboratively create and launch a school drama program. Could he/they accomplish the task? Could he/they raise the necessary funds? Would students attend? What would the community, the Elders, his colleagues, or the school district think about his pledge?

The impossibility of answering the question about the future to which the event of obligation guides usits unanswerability - is the answer to the question. As an event, obligation belongs to a future that none of us can see coming, "over which neither teacher nor student has disposal, what neither one knows or foresees or commands" (Caputo, 2012b, p. 29). Obligation calls each of us to do our best "in an impossible situation," that is, "to see what is possible," to "see what comes" (p. 30).

To what future does it call us forth? The unknown!

Faith in the Unexpected as a Call to Character

"[W]e are not satisfied with what exists and...we are haunted by what insists" (Caputo, 2012, p. 32)

The teachers encountered in the foregoing pages bear witness to Caputo's (2012b) declaration that, "whoever enters the spectral space of the school is answering a call, responding to some spirit calling us together here in common cause" (p. 30). Haunted by obligation, in that place called school where the self meets the world (Ruti, 2014) — the good and the bad of it-teachers actively attempt to answer the call of obligation and to be faithful to the unexpected event that obligation always is.

The call of obligation-as event-creates uneasiness; it cuts teachers off from "the comforts of a deep and reassuring ground" (Caputo, 1993, p. 239) offered by contractual duties or professional standards. Teachers want to do more than survive in classrooms; they seek meaningfulness and desire authenticity in their work and relationships. In the midst of teachers' ongoing efforts to create meaningfulness in dayto-day life in the classroom, events have a way of taking them off course, without warning, creating upheaval and shattering the shell of teachers' usual preoccupations. Unease signals to teachers that they need to achieve a better correspondence between their ideals and the actualities of classroom life, even 
when those ideals deviate from the cultural practices of schooling or the profession, where everything is governed by a strong form of ethics (i.e., run by rules) so that nothing is unruly, and there are no surprises. With Caputo (2012a/b), we wonder if it is even possible to imagine a school in which we have prevented the event and banished all the invisible spirits that haunt the halls of schools. Without obligation as event, the school is absorbed into the quid pro quo sanity of the contractual world wherein teachers have been driven to act as if there is no event, as if there were no promises to be made and to be kept.

Faith in the unexpected-a teacher's capacity to respond to the alarm bells of obligation, to hope for the best, to make the best of events - is what ultimately provokes and sustains each teacher's singularity as an ethical subject, their irreplaceability and inimitability in particular moments, summoning the teacher beyond complacency and toward response. It is during such moments, paradoxically, that it becomes necessary to suspend a search for meaning. There may be no rhyme nor reason for what occurs, no logos or telos. There may only be the question, "What has to be done?" In such moments, one is compelled to follow the pulse of one's passion (Ruti, 2014), rather than rely on routine responses; even virtues can harden into habits, which is why empathy and interpersonal identification can be so misleading and deceptive. Each teacher in the foregoing stories had to be inventive; caught, as it were, between degrees of freedom and unfreedom, each had to live between contractually defined duties and the promissory relation of obligation (Janzen \& Phelan, 2019). Each teacher-even Cecille who chooses to leavedecides to reside in a place of refusal, as if stating, "I'd rather not do business-as-usual." This is why there is something counter-institutional, counter-professional about a teacher's character; "why it is impossible to talk about character without talking about inherent rebelliousness of passion" (Ruti, 2014, p. 13).

Obligation as an event demands "an unconditional faithfulness" (Ruti, 2014, p. 128). It asks teachers to hold their ground and not to betray it via laziness, indifference, or fear when others tell them that its "calling requires too much devotion or dedication or is itself an illusion that may take us in harmful directions" (p. 128). To succumb to obligation is not the same as self-sacrifice, however. We are not suggesting that teachers relinquish professional autonomy and embrace dangerous saviour fantasies. Neither do we wish to patronize teachers by asserting their courage in the face of "exhaustingly difficult" work, where "rewards... remain sometimes intangible, often rare, and always uncertain" (Block, 2014, p. 54). Ours is not an ideology of self-abnegation that demands that teaching is all about the students, obscuring teachers' own interests and motivations even from themselves (Grumet, 2014). Our interest here is in what Ruti (2014) characterizes as self-surrender or openness.

Who we become as educators and what we hope to convey to our teacher candidates depends in large part on how we encounter and interact with the world—our students, their parents, our colleaguesaround us. Our impact on one another can be substantial because as human beings we are "precariously open" (Ruti, 2014, p. 80) in all our complexity (conscious and unconscious desires, for example). Our students will always be a little inscrutable to us, given that, "what goes on between people-the unconscious portion of relationality-is always a little ambiguous" (p. 81). However, given that, to some degree, we "share a common sociocultural environment" (p. 81), we can begin to understand one another at least in part. Moreover, we have no idea where the webs of relationality, into which we insert ourselves, will take us. It takes courage to cope with ambiguity; it requires conscious retrospective 
deliberation, spinning and re-spinning intricate tapestries of meaning that lend weightiness to professional life. Lived in this way, teaching is a pursuit in which one experiences oneself as forever incomplete, never fully actualized or realized.

Obligation is a call of character; it has "a vocational force," provoking us, evoking our response, and potentially transforming us (Caputo, 2012, p. 31). The challenge for teacher education lies, in part, in nurturing faith in the unexpected and helping teacher candidates appreciate that, though often a "quite inscrutable directive" (Ruti, 2014, p. 20), obligation compels teachers to keep rewriting their story line as teachers. So, while the call of obligation offers teachers a future, however spectral, it can also destabilize their sense of professional identity. Yet, there is no alibi for teachers; they must answer in and with their lives, daily.

\section{References}

The Alberta Teachers' Association. (2018). Appendix B: Professional Code of Conduct. https://www.teachers.ab.ca/News\%20Room/Publications/Substitute\%20Teachers/Pages/Appendix\%20B.aspx

Block, A. (2014). The classroom: Encounter and engagement. Palgrave.

Caputo, J. D. (1993). Against ethics: Contributions to a poetics of obligation with constant reference to deconstruction. Indiana University Press.

Caputo, J. (2012a). Teaching the event: Deconstruction, hauntology, and the scene of pedagogy. In Claudia W. Ruitenberg (Ed.), Philosophy of education yearbook. Philosophy of Education Society.

Caputo, J. D. (2012b). Teaching the event: Deconstruction, hauntology, and the scene of pedagogy. Philosophy of Education Archive, 23-34.

Grumet, M.R. (2014). The question of teacher education. LEARNing Landscapes, 8(1), 21-26.

Huebner, D. (1975). Curricular language and classroom meanings. In W. Pinar (Ed.), Curriculum theorizing: The reconceptualists (pp. 217-237). McCutchan.

Janzen, M. D., \& Phelan, A. M. (2015). The emotional toll of obligation and teachers' disengagement from the profession. Alberta Journal of Educational Research, 61(3), 347-350.

Janzen, M. D., \& Phelan, A. M. (2019). "Tugging at our sleeves": Understanding experiences of obligation in teaching. Teaching Education, 30(1), 16-30.

Lingis, A. (1994). The community of those who have nothing in common. Indiana University Press.

Noddings, N. (1984). Caring: A relational approach to ethics and moral education (2nd ed.). University of California Press.

Pinar, W. F. (2020). Moving images of eternity: George Grant's critique of time, teaching and technology. University of Ottawa Press.

Ruti, M. (2014). The call of character: Living a life worth living. Columbia University Press. 
Scott, C. E. (1995). Caputo on obligation without origin: Discussion of against ethics. Research in Phenomenology, 25(1), 249-260.

Taubman, P. (2009). Teaching by numbers: Deconstructing the discourse of standardized accountability in education. Routledge.

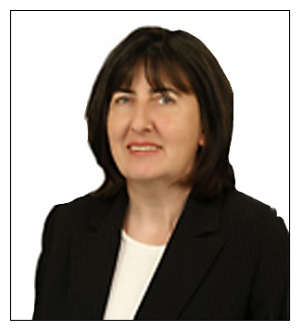

Emma Anne Phelan is a Professor in the Department of Curriculum and Pedagogy at the University of British Columbia, and Honorary Professor at the Education University of Hong Kong. Her research focuses on the intellectual and political freedom of teachers and on the creation of teacher education policies, programs, and practices that support that end.

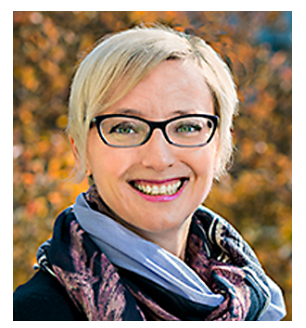

Melanie Janzen is an Associate Professor in the Department of Curriculum, Teaching and Learning in the Faculty of Education at the University of Manitoba. Her research is in curriculum studies and teacher education. Her research explores the inter-related workings of power and discourses, particularly as they relate to the construction of the identities of teachers and the ongoing marginalization of children. 